\title{
Seasonal variation in admissions of psychiatric patients and its relation to seasonal variation in their births
}

\author{
E. H. HARE \\ From the Bethlem Royal Hospital, Beckenham, Kent
}

S. D. WALTER

From the School of Medicine, Department of Epidemiology and Public Health, Yale University, USA

SUMMARY Inpatient admissions to all psychiatric hospital beds in England and Wales in 1970-73 were studied by month of admission for eight diagnostic groups. The admission rates for schizophrenia showed a pronounced seasonal variation, with a maximum in summer. The seasonal pattern for schizophrenia was very similar to the one shown for mania, although somewhat less marked. The admission rates for neurosis and for the large group of 'all other non-psychotic mental illness' showed little evidence of seasonal variation, and such variation as there was could largely be explained by social factors. In schizophrenic and manic patients, the pattern of seasonal admissions (peak months July and August) is similar to the pattern reported for their births (peak months February and March). This is consistent with the hypothesis of an abnormal seasonal pattern of parental conception as the cause of the abnormal birth pattern.

It has been known since the time of Esquirol that the number of patients admitted to mental hospitals tends to be higher in the summer than in the winter; and there has been a general consensus since the paper by Kollibay-Uter (1921) that the fluctuations, so far as psychotic cases are concerned, have a biological rather than a social cause. The literature has been reviewed by Abe (1963). For the functional psychoses (schizophrenia and manicdepression), cyclic variation in admission rates, with a peak in early summer, has been reported from Zurich (Meier, 1922), Wisconsin (Petersen, 1934), and Japan (Abe, 1963). For England and Wales, a similar seasonal variation in admissions for mania has been reported by Symonds and Williams (1976). But there have been no reports (apart from that of Faust and Sarreither (1975) who give no figures) on the seasonal admissions of non-psychotic patients; and there remains some uncertainty how far the variation described in psychotic cases may be a feature of all diagnostic categories and so perhaps might be the consequence of a fluctuating availability of inpatient beds.

We report here on seasonal variation in admissions of psychiatric patients in England and Wales by diagnostic groups, and compare psychotic with non-psychotic cases. We were led to make this study for the following reason. There is now good evidence that patients with schizophrenia, mania, and (although less well substantiated) psychotic depression are born more often than expected in the first quarter of the year (Hare, 1975a, b). Further studies (Hare, 1976; McNeil et al., 1976) indicate that the siblings of such patients have the same abnormal seasonal birth pattern. This supports the hypothesis that the parents of patients with a functional psychosis have an abnormal pattern of conception. It is well accepted that the parents of such patients often have the constitutional traits of schizothymia or cyclothymia. If there is a seasonal variation of biological origin in the onset or severity of the functional psychoses (as reflected in the admission rates), then there is likely to be a similar rhythm in the corresponding constitutional traits; and if, as it is not unreasonable to suppose, this leads to a heightening of sexual drive in the late spring, that would account for the excess of births of the patients in the early months of the year. But the abnormal seasonal pattern of births of psychotic patients is not found for patients with neurosis or personality disorder, and on the parental conception hypothesis we should expect a relative absence of 
rhythmicity in the onset or severity of disorders due to neurosis and personality disorder and hence an absence of a cyclical seasonal variation in their admissions, except in so far as variation might be caused by social factors.

\section{Method}

Through the Mental Health Enquiry of the Department of Health and Social Security (DHSS), routine data are collected on all admissions to psychiatric hospitals and units in National Health Service hospitals in England and Wales. The DHSS has made available to us information on the yearly numbers of first and other admissions during 1970-73, by month of admission and by eight diagnostic groups. The DHSS has also given us information by month of birth and the same diagnostic groups, for all patients who were born in England and Wales and were admitted for the first time to a psychiatric bed in England and Wales during 1970-75.

\section{Results}

Table 1 gives the total monthly admissions (sexes combined) for the eight diagnostic groups over the four-year period. Inspection shows-and this can readily be confirmed by calculating the rates to eliminate the effect of the different number of days in the months-that there is a marked seasonal variation in admissions for schizophrenia, with a maximum in June and July. But our concern is to search for a seasonal variation which cannot readily be attributed to social factors, so we first tried to allow for seasonal variation common to all diagnostic groups which might reasonably be attributed to social factors. In seven of the eight diagnostic groups (the exception is the group of 'other psychoses') the number of admissions in January is notably higher than in December or February. The most probable explanation of this is that patients are not so readily admitted to hospital over the Christmas holiday in December $I$ and that the resulting backlog is to some extent made up in January. This explanation is supported by the fact that sickness absence decreases in Christmas week and increases in the first week in $\stackrel{9}{\rightarrow}$ January (Pocock, 1974). August is also a month in 을 which the number of admissions tends to be lower than in the months immediately before or after, $\frac{\bar{c}}{\partial}$ and this again is likely, in part at least, to be $\stackrel{\mathbb{Q}}{\Omega}$ due to the effect of the August holidays with some backlog being made up in September.

If this is accepted, then the effect of the winter $\vec{\circ}$ and summer holidays on the numbers of admissions $\overrightarrow{\vec{\omega}}$ can to some extent be allowed for by considering $\stackrel{\omega}{\omega}$ numbers of admissions in six two-monthly groupsthat is, December-January, February-March, etc. ? Figure 1 shows the rates of admission, in two-month ${ }_{\mathrm{N}}^{\omega}$ groups, for four diagnoses. Schizophrenia and mania $\overrightarrow{-}$ show a fairly smooth seasonal variation, quite $\vec{v}$ different from the neuroses. For psychotic depression, 을 the cycle of variation is similar to that of mania but is less marked and its peak occurs about a mont 3 earlier.

We need to consider whether the seasonal pattem $)$ of admissions will be influenced by the age $\overrightarrow{0}$ patients. The diagnostic group with the largeș variation in monthly admission rates is the group of 'other psychoses' which has a relatively higher admission rate for the three-month period DecemberFebruary than any other group. 'Other psychoses' contain the large group of senile psychoses and the high admission rates for December to February are understandable in terms of the effect of winter on the general health of elderly persons. We have no figures for age at admission but it seems unlikely

Table 1 Number of admissions (all ages, sexes together) to psychiatric beds in England and Wales 1970-73 by diagnosis and month of admission

\begin{tabular}{|c|c|c|c|c|c|c|c|c|}
\hline Month of admission & $\begin{array}{l}\text { Schizo- } \\
\text { phrenia }\end{array}$ & Mania & $\begin{array}{l}\text { Psychotic } \\
\text { depression }\end{array}$ & $\begin{array}{l}\text { Other } \\
\text { psychoses }\end{array}$ & $\begin{array}{l}\text { Neurotic } \\
\text { depression }\end{array}$ & $\begin{array}{l}\text { Other } \\
\text { neuroses }\end{array}$ & $\begin{array}{l}\text { Personality } \\
\text { disorder }\end{array}$ & $\begin{array}{l}\text { All other } \\
\text { non-psychotic } \\
\text { mental illness }\end{array}$ \\
\hline $\begin{array}{l}\text { January } \\
\text { February } \\
\text { March }\end{array}$ & $\begin{array}{r}10750 \\
9368 \\
10289\end{array}$ & $\begin{array}{l}1596 \\
1381 \\
1409\end{array}$ & $\begin{array}{l}7036 \\
6379 \\
7048\end{array}$ & $\begin{array}{r}11279 \\
9353 \\
9453\end{array}$ & $\begin{array}{l}4651 \\
4288 \\
4656\end{array}$ & $\begin{array}{l}4543 \\
4066 \\
4289\end{array}$ & $\begin{array}{l}5005 \\
4421 \\
4843\end{array}$ & $\begin{array}{l}20653 \\
18101 \\
19746\end{array}$ \\
\hline $\begin{array}{l}\text { April } \\
\text { May } \\
\text { June }\end{array}$ & $\begin{array}{l}10059 \\
10814 \\
11075\end{array}$ & $\begin{array}{l}1480 \\
1663 \\
1714\end{array}$ & $\begin{array}{l}6967 \\
7208 \\
7573\end{array}$ & $\begin{array}{l}9042 \\
9691 \\
9758\end{array}$ & $\begin{array}{l}4370 \\
4720 \\
4731\end{array}$ & $\begin{array}{l}3980 \\
4160 \\
4145\end{array}$ & $\begin{array}{l}4568 \\
4849 \\
4931\end{array}$ & $\begin{array}{l}19085 \\
20541 \\
20831\end{array}$ \\
\hline $\begin{array}{l}\text { July } \\
\text { August } \\
\text { September }\end{array}$ & $\begin{array}{l}11383 \\
10720 \\
10813\end{array}$ & $\begin{array}{l}1824 \\
1746 \\
1641\end{array}$ & $\begin{array}{l}7286 \\
7025 \\
7048\end{array}$ & $\begin{array}{l}9924 \\
9447 \\
9029\end{array}$ & $\begin{array}{l}4677 \\
4322 \\
4471\end{array}$ & $\begin{array}{l}4164 \\
3928 \\
4010\end{array}$ & $\begin{array}{l}5274 \\
4920 \\
4635\end{array}$ & $\begin{array}{l}21148 \\
19629 \\
19783\end{array}$ \\
\hline $\begin{array}{l}\text { October } \\
\text { November } \\
\text { December }\end{array}$ & $\begin{array}{r}10623 \\
9946 \\
9367\end{array}$ & $\begin{array}{ll}1 & 675 \\
1 & 578 \\
1 & 427\end{array}$ & $\begin{array}{l}7285 \\
7070 \\
6588\end{array}$ & $\begin{array}{l}9365 \\
9209 \\
9357\end{array}$ & $\begin{array}{l}4856 \\
4528 \\
3940\end{array}$ & $\begin{array}{ll}4 & 382 \\
4 & 091 \\
3 & 255\end{array}$ & $\begin{array}{l}4952 \\
4798 \\
4375\end{array}$ & $\begin{array}{ll}20 & 630 \\
20 & 131 \\
18 & 535\end{array}$ \\
\hline Total admissions & 125207 & 19134 & 84513 & 114907 & 54210 & 49013 & 57571 & 238813 \\
\hline
\end{tabular}




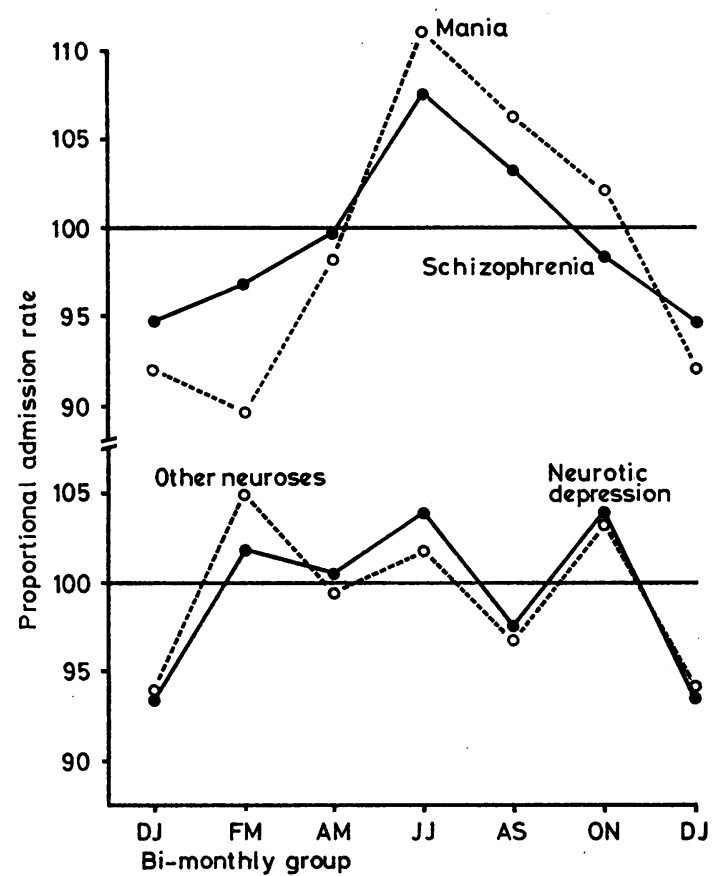

Fig. 1 Two-monthly admission rates, England and Wales 1970-73, for four diagnostic groups. Rates expressed as proportion, per cent, of average daily rate for the year.

that, apart from the senium, age will have much influence on season of admission. Schizophrenia and mania have very similar seasonal patterns of admission but have widely different age distributions. On the other hand, the distribution of schizophrenic patients (when the sexes are combined) is commonly very similar to that of neurotic patients (Hare et al., 1971), yet the seasonal distribution of admissions in the two diagnostic groups is very different.

The effect of gender on seasonal variations in admission must also be considered. We have no figures for this but the admission figures given for mania by Symonds and Williams (1976) show a monthly distribution which is similar for the sexes $\left(\chi_{11}^{2}=8 \cdot 5, P>0 \cdot 5\right)$. In so $f a r$ as seasonal variation in admission rate may be caused by biological variations in severity, we should not expect to find any marked sex difference.

In so far as social causes for admission are operative, one might expect that the more severe the illness, the more likely it is that the admission rate will be independent of season. This may explain why, for the month of December (as opposed to November and January), the proportional admission rates for schizophrenia and mania are higher than for neurosis. Yet for the year as a whole, the functional psychoses show much more seasonal variation in admission rates than the neuroses or personality disorder; and indeed, of all the diagnostic groups, those with the least seasonal variation are the neuroses.

The differences between the diagnostic groups in seasonal admission rates are generally similar for each of the four years of admissions. Table 2 compares schizophrenia with neurosis in this respect. The data from the DHSS also show that within each diagnostic group the seasonal pattern for first admissions is similar to that for all admissions.

Table 2 Number of admissions for schizophrenia by month and year of admission, expressed as percentage of the numbers expected from admissions for neurosis

\begin{tabular}{|c|c|c|c|c|c|}
\hline $\begin{array}{l}\text { Month of } \\
\text { admission }\end{array}$ & 1970 & 1971 & 1972 & 1973 & $1970-73$ \\
\hline $\begin{array}{l}\text { January } \\
\text { February } \\
\text { March }\end{array}$ & $\begin{array}{l}93 \\
87 \\
95\end{array}$ & $\begin{array}{l}98 \\
97 \\
92\end{array}$ & $\begin{array}{l}94 \\
96 \\
95\end{array}$ & $\begin{array}{r}100 \\
90 \\
99\end{array}$ & $\begin{array}{l}96 \\
92 \\
95\end{array}$ \\
\hline $\begin{array}{l}\text { April } \\
\text { May } \\
\text { June }\end{array}$ & $\begin{array}{r}97 \\
108 \\
107\end{array}$ & $\begin{array}{r}105 \\
99 \\
102\end{array}$ & $\begin{array}{r}94 \\
97 \\
103\end{array}$ & $\begin{array}{r}102 \\
98 \\
99\end{array}$ & $\begin{array}{r}99 \\
100 \\
103\end{array}$ \\
\hline $\begin{array}{l}\text { July } \\
\text { August } \\
\text { September }\end{array}$ & $\begin{array}{l}107 \\
115 \\
103\end{array}$ & $\begin{array}{l}108 \\
100 \\
103\end{array}$ & $\begin{array}{l}100 \\
107 \\
112\end{array}$ & $\begin{array}{l}109 \\
108 \\
102\end{array}$ & $\begin{array}{l}106 \\
107 \\
105\end{array}$ \\
\hline $\begin{array}{l}\text { October } \\
\text { November } \\
\text { December }\end{array}$ & $\begin{array}{r}94 \\
92 \\
106\end{array}$ & $\begin{array}{r}95 \\
97 \\
106\end{array}$ & $\begin{array}{r}101 \\
94 \\
109\end{array}$ & $\begin{array}{r}89 \\
97 \\
109\end{array}$ & $\begin{array}{r}95 \\
95 \\
107\end{array}$ \\
\hline $\begin{array}{l}\text { Total admissions } \\
\text { Schizophrenia } \\
\text { Neurosis }\end{array}$ & $\begin{array}{ll}33 & 047 \\
26 & 131\end{array}$ & $\begin{array}{ll}31 & 305 \\
26 & 302\end{array}$ & $\begin{array}{l}30493 \\
26305\end{array}$ & $\begin{array}{l}30362 \\
24485\end{array}$ & $\begin{array}{l}125207 \\
103223\end{array}$ \\
\hline$x^{2}$ (11 d.f.) & 90.4 & $31 \cdot 2$ & $49 \cdot 7$ & $53 \cdot 3$ & $149 \cdot 2$ \\
\hline
\end{tabular}

The seasonal trend for the admission of schizophrenic and manic patients can be analysed in terms of a comparison with other diagnoses by the method of Walter and Elwood (1975). The idea of adjusting the frequencies of an event (for example, an admission for schizophrenia) in a numerator according to the frequencies of another event (for example, an admission for mania) in the denominator which does not include the numerator is a slightly new application of this method. The rationale for this is that one supposes that both events are seasonally distributed, but that the adjustment for the comparison event (the denominator) will reveal the 'true' seasonal pattern in the event of primary interest (the numerator). In the particular applications here, one might imagine that new cases of a disorder are seasonal, but that the probability of such cases being recognised and becoming hospital admissions is also seasonal. By weighting according to another appropriate disorder, one attempts to remove this nuisance seasonal trend in diagnosis and to expose the underlying trend in disease incidence. 
The results of such an analysis are shown in Tables 3 and 4. In these the two groups of neuroses have been combined into a single category, since it is clear from Fig. 1 that they have a similar seasonal pattern of admission. We think neurosis is the most suitable diagnostic category to compare the admission trends in schizophrenia and mania, because the category of all other non-psychotic mental illness includes a considerable proportion (probably not less than $50 \%$ ) of patients given the diagnosis 'depression not otherwise specified' and because personality disorder is not, technically speaking, an illness. Yet if instead we take the group of all non-psychotic disorders-neurosis, personality disorder, and all other non-psychotic mental illness together-the adjusted seasonal trend for schizophrenia and mania still departs very significantly from expectation.

Our findings for seasonal trends in admission may be compared with the seasonal trends in births of psychotic patients. Table 5 shows the monthly distribution of births of patients born in 1921-55 and
Table 3 Significance of seasonal trend in admissions for schizophrenia, adjusted for various comparative diagnoses

\begin{tabular}{lcl}
\hline Comparative diagnosis & $\begin{array}{l}\chi_{2}^{2} \text { for adjusted } \\
\text { seasonal trend } \\
\text { in schizophrenia }\end{array}$ & $\begin{array}{l}\text { Month of } \\
\text { schizophrenia } \\
\text { peak (adjusted) }\end{array}$ \\
\hline Psychotic depression & 32.6 & mid July \\
Other psychoses & 393.7 & late July \\
Neurosis & 140.7 & late July \\
Personality disorder & 41.0 & early July \\
All other non-psychotic & 58.1 & early July \\
mental illness & 69.4 & mid July \\
All non-psychotic disorder* & &
\end{tabular}

*Neurosis, personality disorder, and all other non-psychotic menta illness

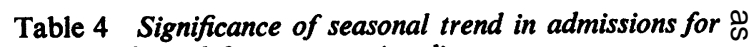
mania, adjusted for comparative diagnoses

\begin{tabular}{|c|c|c|}
\hline Comparative diagnosis & $\begin{array}{l}\chi_{2}^{2} \text { for adjusted } \\
\text { seasonal trend } \\
\text { in mania }\end{array}$ & $\begin{array}{l}\text { Month of } \\
\text { mania } \\
\text { peak (adjusted) }\end{array}$ \\
\hline $\begin{array}{l}\text { Neurosis } \\
\text { Personality disorder } \\
\text { All other non-psychotic }\end{array}$ & $\begin{array}{l}87 \cdot 7 \\
46 \cdot 8\end{array}$ & $\begin{array}{l}\text { mid August } \\
\text { mid August }\end{array}$ \\
\hline $\begin{array}{l}\text { mental illness } \\
\text { All non-psychotic disorder }\end{array}$ & $\begin{array}{l}50 \cdot 7 \\
58 \cdot 6\end{array}$ & $\begin{array}{l}\text { early August } \\
\text { mid August }\end{array}$ \\
\hline
\end{tabular}

Table 5 Numbers, by month of birth and diagnosis, of all patients who were first admitted to a psychiatric bed in England and Wales 1970-75 and who were born in England and Wales 1921-55

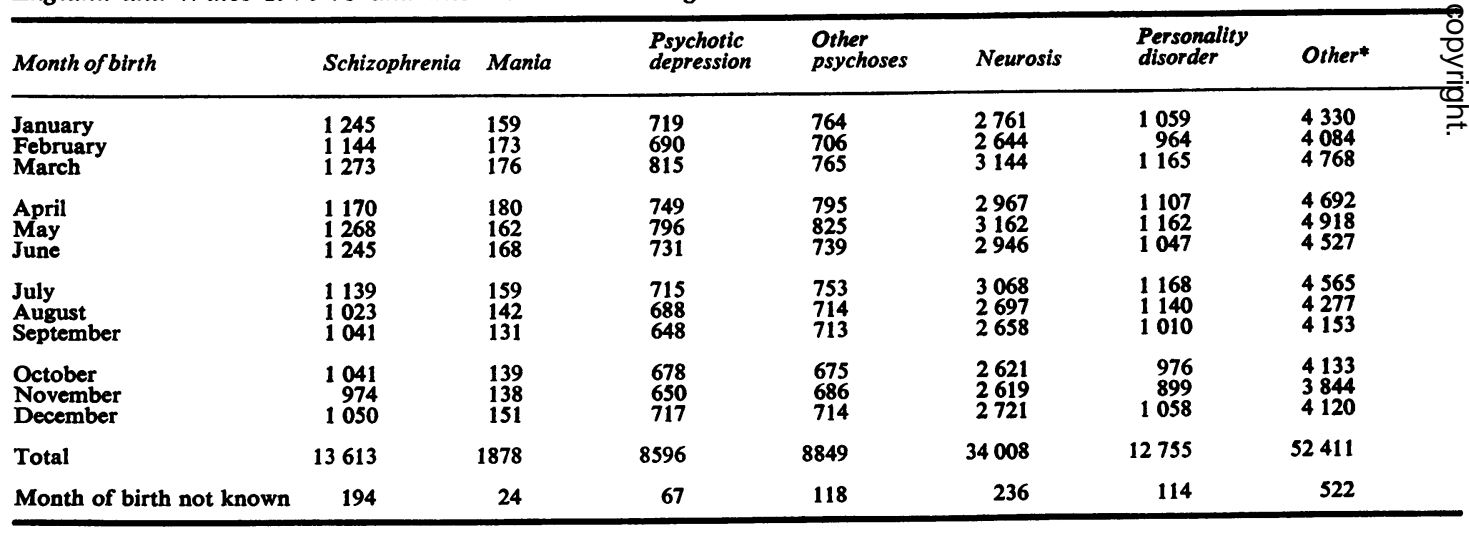

*All other non-psychotic mental illness

first admitted in 1970-75. The relationship between the distribution of these patients' births and that of all live births in the general population has been reported elsewhere (Hare, 1975a, b): for patients with schizophrenia and mania, there is a significant excess (over expectation) of births in the first quarter of the year. Table 6 shows that the seasonal trends of births of patients with schizophrenia or mania are significantly different from that of neurosis when examined by the test of Walter and Elwood (1975). If the monthly number of births and admissions for schizophrenia and mania are expressed as a proportion of the corresponding numbers for neurosis, the result (as a three-month running average) can be seen in Fig. 2 . It is worth $\frac{7}{2}$ noting that the size of the seasonal swing is similar for births and for admissions in both diagnostic $N$ groups. For schizophrenia, the estimated amplitude of variation (the percentage change from the average rate to the maximum rate) is $4.9 \%$ for births and $4.7 \%$ for admissions. For mania, the corresponding figures are $8 \cdot 3 \%$ and $9.5 \%$. 
Table 6 Significance of seasonal trend in births for various diagnoses, adjusted for seasonal trend in births for neurosis

\begin{tabular}{|c|c|c|c|}
\hline Diagnosis & $\begin{array}{l}\chi_{2}^{2} \text { for adjusted } \\
\text { seasonal trend }\end{array}$ & $\boldsymbol{P}$ & Month of peak \\
\hline \multirow[t]{2}{*}{$\begin{array}{l}\text { Schizophrenia } \\
\text { Mania } \\
\text { Psychotic depression } \\
\text { Other psychoses } \\
\text { Personality disorder } \\
\text { All other non-psychotic } \\
\text { mental illness }\end{array}$} & $\begin{array}{r}15 \cdot 5 \\
6 \cdot 1 \\
5 \cdot 2 \\
2 \cdot 5 \\
2 \cdot 7\end{array}$ & $\begin{array}{l}<0.001 \\
<0.05 \\
\text { NS } \\
\text { NS } \\
\text { NS }\end{array}$ & $\begin{array}{l}\text { Late February } \\
\text { Late February } \\
\text { Late January } \\
\text { Late December } \\
\text { Late August }\end{array}$ \\
\hline & 0.75 & NS & Early June \\
\hline
\end{tabular}

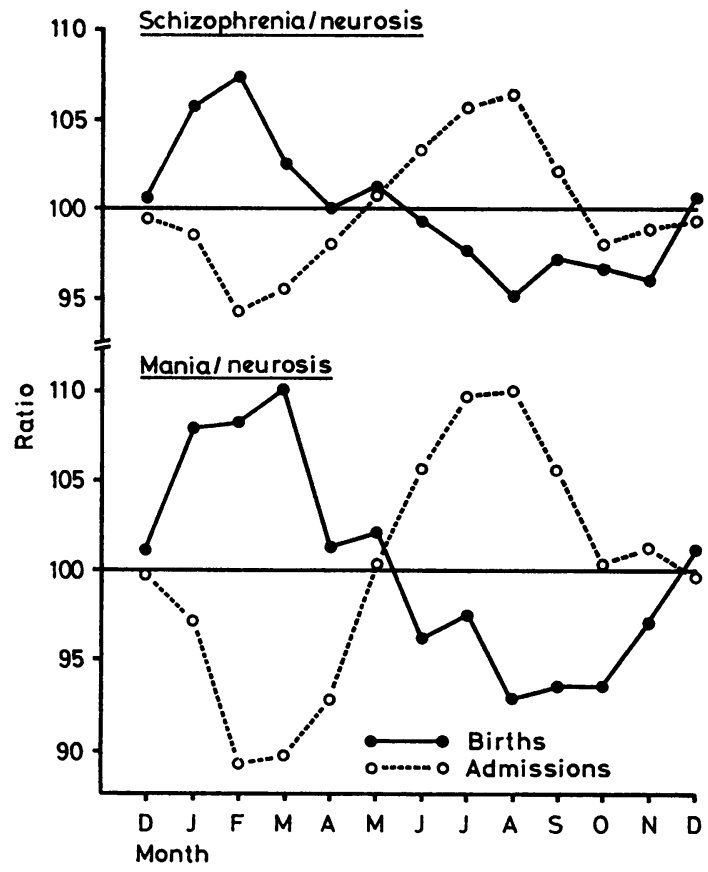

Fig. 2 Monthly births and admissions for schizophrenia and mania, expressed as a percentage of the number expected on the basis of births and admissions for neurosis: three-monthly running averages.

Births of 13613 schizophrenic, 1878 manic, and 34008 neurotic patients born in England and Wales 1921-55 and first admitted there 1970-75. Admissions (all ages) in England and Wales 1970-73; 125207 for schizophrenia, 19134 for mania, 103233 for neurosis.

\section{Discussion}

These findings confirm those from other countries of a marked cyclic variation in admissions for schizophrenia. Both in absolute numbers, and in comparison with admissions for neurosis, admissions for schizophrenia had a maximum about July and a minimum about January. The same seasonal variation was found for mania (sexes combined). Admissions for psychotic depression showed the same seasonal trend as those for mania but to a lesser degree. It is worthy of note that the smaller seasonal variation in admissions for psychotic depression, as compared with mania, also occurs for the births. One might have expected that these two diagnostic groups would show a similar degree of seasonal variation. A possible explanation of the smaller variations in psychotic depression is that this group comprises bipolar and unipolar types and that it is only the bipolar type which shows seasonality.

Abe (1963) allowed for the possibility that the seasonal variation in admissions might be caused by fluctuations in the availability of beds by excluding hospitals in which the number of patients was more than $2 \%$ in excess of the number of registered beds. In England and Wales there are no figures for overcrowding in mental hospitals during 1970-73; but the fact that the total number of patients decreased from 120000 in 1966 to 108000 in 1970 and then steadily to 95000 in 1973, while the yearly numbers of admissions remained practically constant during 1970-73 (Department of Health and Social Security, 1977), strongly suggests that shortage of beds was not likely to have been a significant factor in the monthly numbers of admissions. Moreover, if such shortage had been a factor, it would probably have applied more strongly to admissions for neurosis and personality disorder than for schizophrenia and mania, yet it is the last two groups that had the more marked seasonal variation. We conclude that the observed variation must mainly be due to biological rather than social causes, and therefore that seasonally varying biological factors are much less marked in non-psychotic mental disorder than in the functional psychoses. This conclusion accords with the hypothesis that the abnormal seasonal pattern of births of patients with functional psychosis is due to an abnormal pattern of parental conception (related to constitutional traits of schizothymia and cyclothymia) in their parents.

Compared with births in the general population or with births of neurotic patients, the seasonal peak of psychotic births occurs about February (Table 6), indicating a peak of parental conception about May. The seasonal peak of psychotic admissions occurs in July and August. This difference in time between the peak for conceptions and for admissions could be accounted for by supposing that a biological over-activity occurs about May both in psychotic patients and in those carrying the corresponding constitutional traits, but that in the former group a further period elapses before the disturbance becomes severe enough to 
necessitate the patient's admission to hospital. It would be possible to test whether patients with schizophrenia or manic-depression become more sexually active in May by studying the month of birth of their children.

Reprints from E. H. Hare, The Bethlem Royal Hospital, Monks Orchard Road, Beckenham, Kent BR3 3BX.

\section{References}

Abe, K. (1963). Seasonal fluctuation of psychiatric admissions, based on the data for seven prefectures of Japan for a seven-year period 1955-61, with a review of the literature. Folia psychiatrica et neurologica Japonica, 17, 101-112.

Department of Health and Social Security (1977). Inpatient Statistics from the Mental Health Enquiry for England 1974. Statistical and Research Report Series No. 17. HMSO: London.

Faust, V., and Sarreither, P. (1975). Jahreszeit und psychische Krankheit. Medizinische Klinic, 70, 467-473.

Hare, E. H. (1975a). Season of birth in schizophrenia and neurosis. American Journal of Psychiatry, 132, 1168-1171.

Hare, E. H. (1975b). Manic-depressive psychosis and season of birth. Acta psychiatrica Scandinavica, 52, 69-79.
Hare, E. H. (1976). The season of birth of siblings of psychiatric patients. British Journal of Psychiatry, 129, $49-54$.

Hare, E. H., Price, J. S., and Slater, E. T. O. (1971). The age-distribution of schizophrenia and neurosis: findings in a national sample. British Journal of Psychiatry, 119, 445-448.

Kollibay-Uter, H. (1921). Über die Jahreskurve geister Erkrankungen. Zeitschrift für Neurologie, 65, 351-363.

McNeil, T., Kaij, L., and Dzierzykray-Royalka, M. (1976). Season of birth among siblings of schizophrenics. Acta psychiatrica Scandinavica, 54, 267-274.

Meier, E. (1922). Die periodischen Jahresschwankungen der Internierung Geisteskranker in der Heilanstatt Bürghölzli-Zürich 1900 bis 1920 . Zeitschrift für die gesamte Neurologie und Psychiatrie, 76, 479-507.

Petersen, W. F. (1934). The patient and the weather. In Mental and Nervous Diseases, volume 3, p. 15. Edward: Michigan.

Pocock, S. J. (1974). Harmonic analysis applied to seasonal variations in sickness absence. Applied Statistics, 23, 103-120.

Symonds, R. L., and Williams, P. (1976). Seasonal variation in the incidence of mania. British Journal is of Psychiatry, 129, 45-48.

Walter, S. D., and Elwood, J. M. (1975). A test for 을 seasonality of events with a variable population at risk. British Journal of Preventive and Social Medicine, 29, 18-21. 